\title{
The Moral Legitimacy of NGOs as Partners of Corporations
}

\author{
Dorothea Baur and Guido Palazzo
}

\begin{abstract}
Partnerships between companies and NGOs have received considerable attention in CSR in the past years. However, the role of NGO legitimacy in such partnerships has thus far been neglected. We argue that NGOs assume a status as special stakeholders of corporations which act on behalf of the common good. This role requires a particular focus on their moral legitimacy. We introduce a conceptual framework for analysing the moral legitimacy of NGOs along three dimensions, building on the theory of deliberative democracy. Against this background we outline three procedural characteristics which are essential for judging the legitimacy of NGOs as potential or actual partners of corporations.
\end{abstract}

$\mathrm{I}^{\mathrm{N}}$

N THE COURSE OF EXTENDING THEIR SUPPLY CHAIN across countries and continents, multinational corporations often escape the regulatory coverage of their home countries and benefit from weak regulatory regimes and lower social and environmental standards in other parts of the world (Kobrin 2009; Arnold and Bowie 2003). In a globalized market environment, nation states often fail to exert regulatory control over companies. Yet, with the massive increase in advocacy or watchdog NGOs who publicly address and fight the social and economic injustices created by corporations over the past two decades, corporate behaviour is exposed to public scrutiny (Dahan, Doh, Oetzel, and Yaziji 2010; Utting 2005; Spar and La Mure 2003; Risse 2004; Bendell 2005; Palazzo and Scherer 2006). Two examples might illustrate the explosion of the number of NGOs, both operating on a national and on a transnational level: in China, the number of environmental NGOs has grown from fifty to 3000 in just five years (Santoro 2009); and the number of NGOs with a consultative status at the United Nations increased from 700 in 1992 to 3287 today (www.esango.un.org).

Advocacy or watchdog NGOs typically claim to represent universal values and a general public interest, calling upon corporations to become engaged in solving the social and environmental problems to which they are connected. This inherently political struggle includes NGOs pushing for change, corporations and NGOs deliberating on problems, and, in the ideal case, both types of organizations collaborating in the provision of public goods on a national and global scale (Braithwaite and Drahos 2000; Kaul, Conceição, Le Goulven, and Mendoza 2003; Vogel 2007). This whole nexus of pressure, deliberation, and public good provision represents a privatization of political activities that have been considered as governmental activities in the past (Margolis and Walsh 2003; Scherer and Palazzo 2007). Both actors, corporations and NGOs, exert "private political authority" because they are non-state actors that "are able to exert legitimate authority in the international system (Hall 
and Biersteker 2002) and effect political outcomes directly rather than through the mediation of states" (Kobrin 2009: 354). The CSR debate has thus far largely focused on conceptualizing the corporate side of this interaction. Several avenues have been examined, such as how corporations participate in self-regulatory activities (Scherer and Palazzo 2011), protect human rights (Matten and Crane 2005) or engage in peace-building activities (Fort and Schipani 2004). These scholars have described what corporations do (Valente and Crane 2010), what they should do (Wettstein 2010), and how their political engagement can gain legitimacy (Palazzo and Scherer 2006). Following up on the existing work on the corporate side of the interaction, our goal is to enrich and extend the picture with a systematic normative analysis of the legitimacy of NGOs as partners of corporations in the provision of public goods. The following questions will guide our reflections: What makes an NGO legitimate as a partner of a corporation? And, upon what criteria should companies base their choice of partner NGOs when striving for the provision of public goods?

Historically, the literature on this interaction has been dominated by an examination of the conflict-oriented relations between the two actors in which NGOs would typically launch campaigns to denounce corporate misbehaviour (Yaziji and Doh 2009). Milestones in this conflict-laden past were the campaigns against Nestlé for advertising the use of infant milk in developing countries in the seventies (e.g., Tucker and Melewar 2005), against Nike for sweatshop working conditions in their Asian factories (e.g., Kapstein 2001), and against Shell for their plan of sinking the oil platform Brent Spar and for their behaviour in the conflict with the Ogoni People in Nigeria (e.g., Livesey 2001). In the meantime, the collaborative dimension of the NGO-business interaction has gained more attention (Nijhof, de Bruijn, and Honders 2008). The role of NGOs in pushing corporations towards change and helping them to develop and implement initiatives that alleviate social and environmental harm and promote the public good has been discussed (e.g., van Huijstee and Glasbergen 2010; Argenti 2004; Dahan et al. 2010). Even though "reliable figures on the number of collaborations between [NGOs] and corporations are not readily available," there is "considerable case study and anecdotal evidence" for this trend (Crane and Matten 2007: 436). In recent years, numerous multi-stakeholder initiatives have been launched, in which NGOs and corporations collaborate in the development of soft law standards. Leading multinational corporations such as Starbucks, McDonalds, Nestlé, and WalMart have started to work with NGOs on supply chain-related social and environmental challenges and have even exposed their own operations to NGO certification. There is a body of literature examining issues such as the conditions that make collaboration strategically feasible (Rondinelli and London 2003), the impact of differing mutual expectations for successful cooperation (Jonker and Nijhof 2006), and the specific importance of NGOs for the longevity and stability of investment projects (Doh and Teegen 2002), to name a few.

While the above-mentioned research on partnerships between NGOs and corporations has delivered rich insights, the legitimacy of NGOs as potential partners and their claims in this emerging arena of private political activities deserves a closer look. We must be aware that the choice of a partner NGO is not just another management decision that can be made instrumentally. Rather, it can be conceived as a 
decision with severe normative consequences. As previously stated, NGOs approach corporations with strong normative claims and their collaborations typically address problems relating to the public good, such as environmental and social issues, which traditionally were regulated by governments. The fact that corporations increasingly and actively contribute to solving such problems in a way that exceeds legal requirements, has led scholars to diagnose a "politicization of the corporation" (Scherer, Palazzo, and Baumann 2006; see also Matten and Crane 2005; Moon, Crane, and Matten 2005). As Palazzo and Scherer (Palazzo and Scherer 2008: 774) argued, "corporate acts of making global rules and producing public goods are considered political and, thus, have to be legitimized vis-à-vis the public." Indeed, surveys have shown that companies are in particular concerned about the accountability and legitimacy of their partner NGOs (Dalberg Global Development Advisors 2007; Forster Company and TwentyFifty Ltd 2005; Schiller 2005). ${ }^{1}$ The reason for this concern is quite obvious. If corporations cooperate with civil society organizations that are perceived as representing the public interest with regards to the issue at stake (e.g., in a project on worker rights in factories), their joint CSR related efforts might gain legitimacy (Roloff 2008). However, choosing a civil society partner with reputational problems can have negative spillover effects for the corporation and its CSR engagement (see e.g., Nijhof, de Bruijn, and Honders 2008; Gartzke 2004; Rondinelli and London 2003; Den Hond and De Bakker 2007; Vachani, Doh, and Teegen 2009).

Against the trend in CSR research to primarily assess the role of corporations in NGO-business partnerships, this article argues in favour of a more critical look at the role of NGOs. It is based on the assumption that if we want to develop an objective view on NGO-business partnerships we need to reflect on the role of NGOs with the same degree of criticism as on the role of corporations. If we furthermore accept that the use of the term NGO is often unclear and that some organizations even purposefully misuse it, it is only reasonable to demand that any group presenting itself as an advocate of civil society or who speaks on behalf of 'the public' should prove its legitimacy. By arguing in favour of a specifically moral legitimacy of partner NGOs and outlining criteria for judging this legitimacy, this article attempts to make a systematic normative contribution to the largely descriptive debate on NGO-business partnerships.

We will proceed as follows: First, we will explain the importance of such a normative analysis by arguing that unlike other stakeholders of corporations, NGOs, with their focus on issues related to the public good, claim to represent universal values. On the basis of these strong normative claims on behalf of the public good, we contend in a first step that from an organizational theory perspective moral legitimacy (Suchman 1995) is the most relevant category to analyze NGO legitimacy. Yet, as we will argue, this conception of moral legitimacy requires further refinement if we want to apply it to actors who explicitly claim to act on behalf of the public good. Since we perceive the interaction between NGOs and corporations to be an inherently political interaction, we derive this refinement from a normative model of political theory, namely deliberative democracy. As we will claim, the moral legitimacy of NGOs as actors on behalf of the public good can be analyzed along three dimensions, 
substantive, structural and procedural. We will discuss these dimensions and show that the procedural dimension provides the most appropriate way of evaluating the legitimacy of NGOs and their normative claims. We conclude with some reflections on further conceptual and empirical research along the lines of this article.

\section{OUTLINING NGOS AND THEIR LEGITIMACY}

\section{NGOs as Special Stakeholders}

In order to develop a conceptual framework for judging the legitimacy of NGOs as corporate partners, we need to have an idea of what NGOs are. A convincing rationale for evaluating the legitimacy of NGOs in their interaction with corporations can be found in the idea of stakeholder responsibility as introduced by Goodstein and Wicks. They argue that "in interdependent relationships, responsibilities between firms and stakeholders work both ways, rather than in one direction" (Goodstein and Wicks 2007: 377) and that it is therefore worth considering not just the responsibility of corporations but also of their stakeholders. In the stakeholder literature, NGOs are characterized as secondary or derivative stakeholders (Phillips 2003) whose connection to the corporation is rather loose and only indirect. Paradoxically, despite this categorization as a second order actor in the stakeholder network of corporations, NGOs play a crucial role in the overall CSR debate (e.g., Nijhof, de Bruijn, and Honders 2008; Doh and Guay 2006; Teegen, Doh, and Vachani 2004; Spar and La Mure 2003; Guay, Doh, and Sinclair 2004; Hendry 2006; Jonker and Nijhof 2006; Arenas, Lozano, and Albareda 2009).

To determine how the legitimacy of NGOs as potential partners for corporations can be examined, we first have to reconstruct the special status which NGOs hold among the broad variety of potential corporate stakeholders. Stakeholder theory has discussed the legitimacy of stakeholder claims towards corporations by asking whether or not a corporation owes moral obligations to specific stakeholders resulting from the interaction of the two (Mitchell, Agle, and Wood 1997; Jones and Wicks 1999). Phillips and Freeman (2008: 107) have described them as "reciprocity-based obligations." Yet, while in general, stakeholders such as employees or investors can be assumed to have a particular interest vis-à-vis the corporation resulting from their direct interaction, NGOs do not belong to the sphere of private associations but rather to the level of the "basic structure of society" (Phillips 2003: 27). Thus, NGO claims are difficult to conceptualize on the basis of reciprocal obligation. However, Phillips (2003) has pointed out that some of those normative claims typically raised by NGOs-for instance those that refer to basic human rights-are valid claims regardless of whether or not they affect the stakeholders of the corporation. Violations of those norms to which the claims refer, can be considered to be wrong, "for reasons prior to any stakeholder obligation" (Phillips 2003: 30). In this sense, NGOs, in particular those with a watchdog or advocacy agenda, are assumed to represent "cosmopolitan" or "higher-order interests" (Teegen, Doh, and Vachani 2004: 471) which transcend their own existence. They are, as Young has argued, "committed to a universalist rather than partisan cause" (Young 2001: 675). Consequently, the most visible role that NGOs adopt vis-à-vis corporations is that of advocacy or 
watchdog organizations who claim to represent the interests of future generations or of current generations of actors who are poor and marginalized and who lack the necessary financial, technological, and educational resources to make themselves heard (Slim 2002; Brown 2008; Chandhoke 2005). NGOs, for instance, make claims on behalf of enslaved children on cocoa plantations in the Ivory Coast, of workers who are exposed to hazardous working conditions in Chinese factories or on behalf of the orang-utans in the rain forests of Indonesia whose habitat is threatened by the expansion of palm oil plantations. NGOs that either target corporations for the social and environmental harm to which they are connected or collaborate with corporations in on behalf of the common good are assumed to represent the public good (Fries 2003) "against the power-driven interests of the state and the profitdriven interests of the economy" (Chandhoke 2005: 359). We do not want to argue that NGOs do not have particular interests. A watchdog NGO might, for instance, get more donations as the result of a spectacular campaign against a corporation. However, our interest here is their legitimacy as partners with regards to universal claims they raise when they target corporations. In this context, NGOs perceive themselves as agents of social transformation which address injustices created by the economic system and corporations as its dominant actors (Arenas, Lozano, and Albareda 2009). Therefore, their claims are of a clearly normative kind.

However, since apparently any organization that is not officially operated by a government or that is not obviously an economic actor can call itself an NGO and raise allegedly public claims in the name of 'the general interest' (Collingwood and Logister 2005; Martens 2002) the question is what determines the legitimacy of those normative claims and of those organizations themselves?

One of the primary strands of research dealing with the question of legitimacy is organizational theory (see e.g., Dowling and Pfeffer 1975; Ashforth and Gibbs 1990; Elsbach and Sutton 1992). The most influential concept has been proposed by Suchman (1995). He defines legitimacy as "a generalized perception or assumption that the actions of an entity are desirable, proper, or appropriate within some socially constructed system of norms, values, beliefs, and definitions" (Suchman 1995: 574).

Suchman differentiates between three legitimation strategies that can be adopted by organizations in order to gain acceptance in society: pragmatic, cognitive and moral. Pragmatic legitimacy is said to rest "on the self-interested calculations of an organization's most immediate audiences" (Suchman 1995: 578). Translated to our research question, pragmatic legitimacy would denote an NGO`s ability to respond to the expectations of its immediately relevant audiences or to even manipulate those expectations in its own interest. Such a self-interested notion of legitimacy is hard to reconcile with our account of NGOs as actors which act on behalf of the common good.

Cognitive legitimacy derives from some "broadly shared taken-for-granted assumptions" (Palazzo and Scherer 2006: 72) about an actor or a claim in its relevant context of reference. The problem with cognitive legitimacy is that it lacks critical reflection because it builds on the assumption of mutual behavioural expectations which are routinized in a way upon which different actors have agreed. The interaction between watchdog NGOs and corporations, however, often takes place in a 
dissensual context where such shared or even routinized expectations are absent, that is a context where it is not clear what the right behaviour, the right values or the right expectations are. Who is responsible for slave labour in the cocoa production in Africa, what should be done and what are the norms that should be applied? When NGOs and multinational corporations struggle with such a problem, they cannot refer to taken-for-granted assumptions that provide routinized answers to these questions. The taken-for-grantedness of actors and claims which underlies cognitive legitimacy is inappropriate for a normative evaluation of NGOs and their claim of representing the common good. While this is true in a local context, it becomes even more problematic on a transnational playing field on which NGOs typically operate when they confront multinational corporations with the social and environmental harm that they cause along their supply chains (Kostova and Roth 2002; Kobrin 2001; Palazzo and Scherer 2006; Swartz 2010).

Moral legitimacy, in turn, reflects "a positive normative evaluation of the organization and its activities," i.e., it rests "on judgements about whether the activity (of an organization, the authors) is "the right thing to do" (Suchman 1995: 579) and it is the result of "explicit public discussion" (Suchman 1995: 585). NGOs often gladly engage in public discussion since, given their lack of economic or political power to become active in other venues, this is the most readily available resource through which they can foster the change they envision; and they particularly focus on stimulating public discussion through campaigns in order to hold corporations accountable for the societal and environmental harm they create. Therefore, moral legitimacy as that type of legitimacy which results from public discussion suggests itself as a promising starting point for judging the legitimacy for NGOs.

Yet, as we argue, if we choose moral legitimacy as the most meaningful type for judging the legitimacy of NGOs, we have to anchor it in a broader conceptual context than foreseen in the debate on organizational legitimacy. Put differently, if we conceptualize NGOs as political actors who make claims on behalf of the common good, we need a political interpretation of moral legitimacy. In what follows, we propose the model of deliberative democracy in order to evaluate the moral legitimacy of NGOs. This model will be succeeded by a conceptual framework which we develop in order to capture the specific legitimacy challenges of NGOs as actors who act on behalf of 'the public good' and which differentiates between three dimensions for judging the moral legitimacy of NGOs, namely structural, substantive and procedural dimensions. We will argue that the procedural dimension offers the most convincing criteria when it comes to judging the legitimacy of NGOs as partners of corporations.

\section{ANALYZING NGO LEGITIMACY AGAINST THE BACKGROUND OF DELIBERATIVE DEMOCRACY}

Any account of moral legitimacy must be linked to a normative theory in order to prevent the attribute 'moral' from boiling down to an empty phrase and in order to gain normative orientation when judging moral legitimacy. The research question at hand specifically calls for a model that provides normative orientation regarding the 
role of NGOs as actors who act on behalf of the public good vis-à-vis corporations. This requirement, we argue, is best met by the theory of deliberative democracy.

Deliberative democracy, which can commonly be described as the normative political theory that corresponds to the moral theory of discourse ethics, has received increasing attention in political theory over the past two decades (Manin 1987; Cohen 1989; Benhabib 1994; Habermas 1996b; Warren 1996; Bohman 1998; Dryzek 2000; Fung 2003; Dryzek 2006) as an alternative to the dominating liberal model of democracy.

A key assumption of the liberal model of democracy is that the legitimacy of political outcomes builds on the decisions of voters aggregated to majority decisions (Buchanan 1987). The deliberative model, in contrast, assumes that legitimacy cannot be achieved in formal political processes alone. While the liberal model leaves no room for political activities outside the traditional governmental institutions (except for the act of voting), the model of deliberative democracy builds on the assumption that the legitimacy of political decisions depends on the embeddedness of those decisions in processes of public deliberation (Habermas 1996b).

The recent rise of deliberative democracy has been supported by the decreasing influence of nation states which created opportunities and necessities for new political actors, i.e., non-state actors such as corporations and NGOs, to enter the stage (Zürn 1999; Habermas 2001; Chambers 2003). In contrast to the liberal model, the deliberative model sees civil society as the sphere of social interaction which lies between the state and the economy and which mediates between the particular and the general (Cohen 1999). To put it simply, it is argued that public reasoning is the best way to test whether specific claims only serve particular interests or whether they (also) serve the public good. According to proponents of deliberative democracy "in pluralistic societies, a common ground on questions of right and wrong, or fair and unfair can only be found through joint communicative processes between different actors" (Scherer and Palazzo 2007: 4). Some scholars have even argued that public deliberation is additionally a school of democracy for citizens, empowering them to use their citizenship rights actively (Cohen 1989; King 2003).

The mobilization of discourses on public problems is a main concern of deliberative democracy and civil society organizations, in particular NGOs, play a key role in this process. As Benhabib has argued, public conversation results from "the interlocking net of these multiple forms of associations, networks, and organizations" (Benhabib 1996: 74). A deliberative dialogue requires that in principle, "all whose interests are actually or potentially affected by the courses of action and decisions which may ensue from such conversations" must have the right to equal participation therein (Benhabib 2002: 36). It thereby does not only consider voters but any actors in civil society as relevant actors in the public sphere. In the deliberative conception, civil society actors adopt the functioning logic of questioning, criticizing and publicizing (Dryzek 1999; Leggewie 2003).

Originally, the debate focused on the relation between governmental decisions and public deliberation. However, as we have argued, political decisions are no longer exclusively made by public actors. For instance, they are not necessarily made manifest in hard law but in soft law such as in the regulatory standards developed by the 
Global Reporting Initiative for CSR reporting, the standards developed by the Fair Labor Association to enforce labor rights and the standards developed by the Forest Stewardship Council to protect rain forests. Therefore, more recently, it has been proposed that CSR should be understood as a political responsibility (Lozano 2001; Rasche and Esser 2006; Palazzo and Scherer 2006; Scherer, Palazzo, and Baumann 2006; Gilbert and Rasche 2007; Scherer and Palazzo 2007; Reynolds and Yuthas 2008) and deliberative democracy has also been suggested as a model to account for the relation between corporate decisions and public deliberation (Palazzo and Scherer 2006; Scherer and Palazzo 2007; Ulrich 2008). As argued, NGOs are seen as the main representatives of civil society which help generate and guide a public discourse and bring together constituencies that lack natural ties (Smith 1998). When they act as stakeholders or partners of corporations, NGOs ideally assume the role of discursive interfaces between corporations and civil society (on the role of NGOs as discursive interfaces between international organizations and a global citizenry see Nanz and Steffek 2004). Therefore, a deliberative understanding of CSR sets the stage for NGOs as potential partners in the corporation's (political) engagement for the common good. Moreover, deliberative democracy advocates a procedural understanding of legitimacy and it connects it to processes of public will formation. Moral legitimacy in this sense depends on the discourses that precede political decisions.

NGO claims on behalf of the common good are made in the context of a modern society which is characterized by growing pluralism. By extending the public sphere beyond the constitutional sphere and by expanding the scope of democratic accountability beyond national borders (Besson and Martí 2006; Dryzek 1999), deliberative democracy gives consideration to the condition of modern societies where there is no shared comprehensive moral or religious view, or simply no objective moral view from nowhere. Since, under these conditions, a material consensus on many normative claims is difficult to achieve, deliberative democracy emphasises the relevance of the process of deliberation itself as the yardstick for the evaluation of legitimate outcomes. It is aware of the possibility that the public process of deliberation might not lead to a consensus but, for instance, to a majority decision with a strong dissenting minority. This situation is referred to as the 'fact of reasonable pluralism' (Rawls 1993; McCarthy 1994; Cooke 2000; Gaus 2003; Moon 2003). In contrast to the fact of mere pluralism as such that purely economic or pluralistic theories of democracies promote (Schumpeter 1947; Downs 1957; Dahl 1956), the fact of reasonable pluralism demands that the diversity of reasonable comprehensive doctrines is not a simple result of class- or self-interest. It rather imposes the normative condition that only doctrines which are the result of the public exchange of arguments are reasonable. This means that world views must be advocated on the grounds of defensible reasons for holding them in order to count as reasonable (Moon 2003).

If we apply this thought to the context of NGOs in their interaction with corporations, we can conclude that, from a deliberative point of view, NGOs that are willing to co-operate with companies must rely on the work of free practical reason when advocating their claims, that is, they must legitimize their claims discursively. As 
we will see in the following, this implies that it is not enough for them to merely refer to their democratic structures or to the public substance of their claims. Instead, they need to adhere to specific procedures, namely they need to be capable of engaging in processes "of reaching understanding that take place through [formal] democratic procedures or in the [informal] communicative network of public spheres" (Habermas 1996a: 299).

While this portrait of deliberative democracy as a background against which to judge the moral legitimacy of NGOs already gives some evidence as to which of the three dimensions introduced in the next section might yield the most meaningful criteria for our task, we do not want to rush into a premature conclusion in favour of procedural criteria. Instead, we will thoroughly point at the limitations of substantive and structural criteria before making our case for judging the moral legitimacy of NGOs along procedural criteria.

\section{A CONCEPTUAL FRAMEWORK FOR JUDGING THE MORAL LEGITIMACY OF PARTNER NGOS}

If we perceive NGOs as actors which act on behalf of the public good, there are three dimensions which suggest themselves for analyzing their legitimacy: structural, substantive and procedural. Analyzing NGO legitimacy along these dimensions represents a new way of systematizing existing criticism about NGO legitimacy and helps us to establish a notion of legitimacy which does justice to the political role which NGOs assume as representatives of the public good in their interaction with corporations.

The structural dimension of the legitimacy of NGOs points to the problem that NGOs represent a constituency which has not elected them. They have no formal democratic legitimacy. Even if they are registered organizations that face some kind of duty on the level of certain nation states, they often cannot be held accountable for their actions on a transnational or extraconstitutional level (Habermas 2001; Zürn 2004; Habermas and Cronin 2006). Greenpeace, for example, has no electoral mandate to represent the environmental claims of citizens vis-à-vis governments and companies. The substantive dimension of the legitimacy refers to the difficulty to determine which NGO claims are legitimate. NGOs often claim to act in the public interest. But how can we decide what is a public interest and what is a private interest? What norms should guide such a judgment?

The procedural dimension of the legitimacy of NGOs relates to the fact that NGOs are generally free to decide which strategy they wish to adopt to approach companies effectively. They are free to choose whether they want to exert pressure on companies or whether they want to collaborate. Especially when opting for the pressure strategy, NGOs sometimes rely on morally arguable tactics of disruption, power politics or even violence, which raise doubts about their commitment to the public good. An extreme example for an NGO that deliberately seeks confrontation and does not shy away from highly controversial tactics in order to reach its goals is the animal rights group named Stop Huntingdon Animal Cruelty (SHAC) which particularly aims at closing down Europe's largest animal testing lab Huntingdon 
Life Sciences. Activists from SHAC have even been suspected of being responsible for desecrating the grave of Novartis CEO Daniel Vasella's mother and of setting fire to Vasella's hunting lodge (Jack 2009; Boyle 2009; Edwards 2009).

As we will argue, substantive and structural criteria are difficult to apply to evaluate the moral legitimacy of NGOs. In the following, we will first advance arguments pointing at the limitations of those criteria and afterwards develop the argument that a normative evaluation of NGO legitimacy should focus on procedural criteria.

\section{Limits of Substantive Criteria for Assessing Legitimacy of NGOs as Partners}

Substantive definitions of legitimate NGOs judge the content of the mission an NGO represents. However, defining a legitimate NGO depending on its mission is a very delicate task. What norms should guide such a judgment? As we have argued, NGOs do often claim to represent universal values. Thus, one substantive criterion for judging the legitimacy of an NGO's claim relates to the universality of the claim. Human Rights NGOs for example often state that they "have a moral right or duty to act or speak out, which is based in the universal values contained in the Universal Declaration of Human Rights, or the legitimate claims on our solidarity of vulnerable people whose rights are not being respected" (International Council on Human Rights Policy 2003: I[52). The opposite of a universal claim is a particularistic claim - as Michael Ignatieff states: "Particularism conflicts with universalism at the point at which one's commitment to a group leads one to countenance human rights violations towards another group" (Ignatieff and Gutmann 2001: 9). Another substantive criterion might be the claim's reference to the idea of the public good - the UN for example defines an NGO's mission by stating that an "NGO is a not-for-profit, voluntary citizens' group, which is organized on a local, national or international level to address issues in support of the public good" (United Nations Department of Public Information 2006). Here, "issues in support of the public good" equal legitimate claims.

Defining the public good is a challenge that has been "a central and characteristic preoccupation of Western thought since classical antiquity" and "has long served as a point of entry into many of the key issues of social and political analysis, of moral and political debates, and of the ordering of everyday life" (Weintraub 1997: 1). However, in modern societies different notions of the good life and consequently also of the public good co-exist and a substantive definition of what is public and what is private, risks excluding interests of minorities from public debate (Benhabib 1992; Banerjee 2000). Modern societies, therefore, are characterized by normative pluralism which manifests itself in a fragmentation of values and the individualization of lifestyles (Beck-Gernsheim and Beck 2002; Friedman and Randeria 2004; Lash 1999; Rorty 1991; Taylor 2007). Yet, as elaborated in our section on deliberative democracy, under the conditions of pluralism, it is very difficult to think of substantive guidelines that hold NGOs accountable for serving the public good (Gray, Bebbington, and Collison 2006). Substantive criteria are thus not an appropriate measure for unequivocally capturing the specific moral legitimacy of NGOs. 


\section{Limits of Structural Criteria for Assessing Legitimacy of NGOs as Partners}

At least three different structural criteria can be advanced for evaluating the legitimacy of partner NGOs: their formal registration with governments or international organizations, their democratic structures, and their connections to corporations and radical groups.

Formal registration with a government or an international organization is one structural measure that could be used for judging the legitimacy of NGOs. A corporation could for example check whether a potential partner NGO is registered as a non-profit organization according to Section 501(c)(3) of the Internal Revenue Code of the United States, which requires nonprofits to provide detailed information about their finances, organizational structure, and programs through an annual information return. This information seeks to confirm that the organization's "activities are primarily for educational, charitable, religious, or scientific purposes and for public, rather than private, benefit" (Ebrahim 2003: 816). The problem with this criterion is that it tells us something about the legal status of NGOs but not necessarily about their moral legitimacy. Legality is only a small part of an organisation's fundamental legitimacy; the wider legitimacy of an NGO, as we argue, is derived morally (Slim 2002: II26). If we rely on formal registration as a criterion, we leave it up to the registration guidelines, as issued by the public body in question, to define NGOs. Moreover, it is hard to conceive of forms of registration that would exclusively apply to NGOs, but not to related associations such as charities, grant-receiving bodies, community-based enterprises etc. (Gray, Bebbington, and Collison 2006; Fries 2003: 235). Additionally, this criterion of evaluation runs into problems if we take into consideration that non-democratic countries such as China also require NGO registration.

Other attempts to judge the legitimacy of NGOs explicitly require those organizations to have democratic structures. One example of a clear-cut attempt to define legitimacy by means of this criterion can be found in the UN resolution on the consultative relationship between the UN and NGOs. The UN states that internal democratic decision-making processes are an indispensable requirement for NGOs to be granted consultative status (United Nations Economic and Social Council 1996). Yet, it is evident that such a general definition does not help to fully capture the legitimacy of NGOs and set them apart from other actors. Radical animal rights activists for example can easily fulfil the criteria established by the UN in its Resolution 1996/31. Moreover, this requirement fails to address the problem of representation since "most people who are being represented are excluded from access to global civil society organizations" (Chandhoke 2005: 362; see also Leggewie 2003). One solution to this problem would be to introduce electoral mechanisms for NGO representatives. Yet, apart from the difficulty of implementing such procedures in practice, assigning formal electoral mechanisms to NGOs misjudges their status as civil society organizations that act outside the formal political institutions.

Finally one could also try to judge the moral legitimacy of NGOs by requiring them to disclose their connections to both corporations and 'activist groups' (Gray, Bebbington, and Collison 2006). The proximity between NGOs and corporations 
is usually disclosed by information on corporate funding. Obviously, if an NGO receives a big part of its funding from one corporation, one might suspect an increased risk of co-optation (Nijhof, de Bruijn, and Honders 2008; Bendell 2005). In other cases, NGOs can be mere front groups which are created by corporations intended to look like NGOs but which act on behalf of the corporate interest. This is a practice that, for instance, has been reported for the tobacco industry (Apollonio and Bero 2007). At the same time, an NGO that cares about its moral legitimacy can be expected to equally disclose its connection to conflict-oriented or even violence-oriented activist groups. However, connections to activist groups are not unambiguous evidence for a lack of legitimacy. To a certain extent, it is desirable for NGOs to be in touch with all those groups who work on the same topics and confront the same actors with their claims. But of course, an NGO which maintains close connections to groups that disregard basic rules of civil behaviour cannot be considered a legitimate partner. All in all, it is difficult, particularly for watchdog and advocacy NGOs, to find the right degree of proximity to more radical groups (Haines 1984). Yet, it becomes evident that structural measures are not adequate for resolving this dilemma. Thus, the structural dimension provides some helpful but not unequivocal indicators for judging the moral legitimacy of NGOs.

Given the limitations of structural and substantive criteria for evaluating the democratic legitimacy of NGOs, we propose to judge NGO legitimacy based on procedural criteria. Since this task requires some further elaboration, we will do so in a new section.

\section{PROCEDURAL CRITERIA FOR JUDGING THE MORAL LEGITIMACY OF PARTNER NGOS}

In this section, we propose and assess three main procedural criteria that could be used to judge the moral legitimacy of partner NGOs and which all can be derived from the idea of deliberative democracy: their commitment to civil behaviour, their discursive orientation, and their orientation towards consensual behaviour. These criteria, it is argued here, must be assessed in the following order: First we must examine whether an NGO acts within the boundaries of civil behaviour because un-civil behaviour precludes the legitimacy of an NGO as a potential partner of a corporation. If the requirement of civil behaviour is fulfilled, we must, as a next step, assess whether the NGO exhibits an orientation that is primarily discursive and consensual. It will be argued that a legitimate partner NGO only resorts to nondiscursive and non-consensual means of action once the discursive and consensual means have been tried out unsuccessfully and are exhausted. In any case, if an NGO deploys non-discursive methods and if it exhibits conflict-oriented rather than consensual behaviour, we must decide whether the circumstances justify this behaviour.

\section{Civil Behaviour}

The first procedural criterion to be assessed when judging the moral legitimacy of partner NGOs is their commitment to civil behaviour. The procedural criterion of civil behaviour, it is argued, is an indispensable requirement for legitimate part- 
ner NGOs. Un-civil behaviour is characterized by an explicit orientation towards conflict combined with the willingness to resort to violence against things or even persons. ${ }^{2}$ NGOs which cross the border into violence cannot be considered legitimate representatives of civil society because their behaviour is literally un-civil (Fowler 2000). This behaviour manifests itself especially in the willingness of some NGOs to put the life of others at risk through their activities. Un-civil behaviour is also reflected in the tactics of some activists leading to material damage when attacking their targets (De Bakker and Den Hond 2008; Den Hond and De Bakker 2007). An association that regularly operates near the border of un-civility and deliberately deploys these tactics against corporations is People for the Ethical Treatment of Animals (PETA)(PETA 2007; Fashion United 2006). Their repeated disruptions of fashion shows suggest that they are not interested in dialogue with companies but rather aim at the destruction at least of those parts of a company that produce fur. A more serious form of un-civil protest is tree spiking. Activist groups like Earth First! hammer nails into trees to discourage logging. However, since these nails normally are not visible to forest workers, the attempt to log a tree threatens their physical integrity because they risk serious injuries (http://www.iww.org).

In general, un-civil behaviour is irreconcilable with the moral legitimacy of an NGO. Un-civil behaviour is non-discursive and it is conflict-oriented instead of consensual. Both criteria-i.e., discursive and consensual behaviour-are crucial if moral legitimacy is understood procedurally. If an NGO resorts to un-civil oppositional activity, it thus loses its legitimacy as a partner for a company and a company can reasonably reject cooperation or even dialogue.

Admittedly, these reflections are somewhat hypothetical if we acknowledge that a very radical group does not have cooperation on its agenda so that companies that are the target of such a group are freed from considerations about effectively cooperating with the originators of the campaign. Nevertheless it is important to reflect on the 'borders of civility' in order to counteract the tendency to use the term civil society in a romanticizing way. We must be aware that in a divided world civil society can also feature groups with decidedly hostile or even murderous intentions (Dryzek 2006). Reflecting on the borders of civility and defining the limits of tolerance with regards to doubtful behaviour of civil society groups that attack corporations, helps corporations to better justify their categorical rejection of any concession to or compromise with such groups.

\section{Discursive Behaviour}

Once we have made sure that an NGO is committed to civil behaviour, we can assess different characteristics of this behaviour. In contrast to un-civil behaviour, civil behaviour can be expressed discursively or non-discursively. In accordance with the model of deliberative democracy, the idealtypical discursive behaviour as exhibited by an NGO which cares about its moral legitimacy consists in its principal willingness to argumentatively clarify its claims and to prove that its demands are not grounded in particular interests but rather in public interests. 
With regards to distinguishing discursive from non-discursive behaviour, it is important to note that, in contrast to un-civil behaviour, resorting to non-discursive (yet civil) behaviour or "critical oppositional activity," as Young calls it (Young 2001: 671), does not preclude the legitimacy of an NGO as a partner of a corporation. Non-discursive civil behaviour is typically adopted by activists and includes actions such as "picketing, leafleting, guerrilla theatre, large and loud street demonstrations, sit-ins, and other forms of direct action, such as boycotts" (Young 2001: 673). If an organization chooses this kind of behaviour it does not attempt "to come to agreement with those who support or benefit from existing power structures" (Young 2001: 674).

Obviously, these actions stand in contrast to the idealtypical discursive behaviour of legitimate partner NGOs. Yet, there are situations legitimately justifying an NGO resorting to non-discursive behaviour in the form of civil opposition. Not every NGO that resorts to non-discursive behaviour can be counted as a chaotic troublemaker. How can non-discursive behaviour be justified within a deliberative approach to legitimacy? With regards to the issue of non-discursive tactics, the limits of substantive criteria for the evaluation of NGO legitimacy once again become clear. Humphrey and Stears have proposed to justify un-discursive behavior by evaluating the moral urgency of a NGO claim (Humphrey and Stears 2006: 415ff.). Yet, as we have argued, in pluralistic societies, it is difficult to reach a consensus on substantive measures which would allow for judging the legitimacy of an NGO. We assume that such consensus is equally difficult to find for judging the moral urgency of a claim. Justifying non-deliberative action based on the 'felt moral urgency' of a claim opens the door to an uncontrolled number of cases in which non-deliberative practices would be justifiable as legitimate.

The justification for an NGO relying on non-discursive means rather than on deliberative action parallels the justification for civil disobedience as put forward in political theory, particularly in deliberative democracy: "the extent of permissible deviation from deliberative norms increases according to the adversity of political circumstances" (Fung 2005: 397). NGOs are allowed to act as "deliberative activists" by forsaking the use of reason for the more common weapons of the political arena if they encounter unfavourable circumstances such as hostility of powerful actors (i.e., extreme failure of the will to reciprocity) or extreme inequality (Fung 2005). As a rough guideline, one could thus state that a legitimate partner NGO only exercises non-discursive behaviour as 'ultima ratio.' With respect to their behaviour towards companies this means: if companies are absolutely unwilling to enter a dialogue with NGOs or if they base their whole interaction on power, NGOs are allowed to leave the path of deliberation and deploy non-discursive methods without losing their moral legitimacy (on the use of different strategies see also Hamann and Acutt 2003: 236-37). One always needs to take into account the circumstances under which the civil society organization adopts this behaviour (on the importance of the question of how activists should behave, see Den Hond and De Bakker 2007: 7). In a recent case, the CEO of Timberland described how Greenpeace forced the company into a discourse on deforestation by launching a non-discursive and conflict-oriented campaign against the company (Swartz 2010). This example shows that symbolic 
conflict-oriented tactics might be useful to force corporations to start a discourse with civil society on the issue at stake. If the political circumstances are highly adverse, or characterized by extreme inequality (Fung 2005), then symbolic conflict-oriented tactics can be justified as a means of ultima ratio.

Ideally, legitimate partner NGOs make their logic for resorting to non-discursive means transparent: Oxfam, for example, never enters partnerships with corporations which are targets of Oxfam campaigns (Billenness 2003). Oxfam thus concedes that it does not exclusively rely on bilateral cooperation with companies but also still uses unilateral attention-seeking methods like campaigning. It pursues discursive and non-discursive strategies but does not simultaneously direct them at the same company.

\section{Consensual Behaviour}

Finally, we can also judge the moral legitimacy of a partner NGO by the extent to which it is oriented towards 'consensual behaviour.' Just like the criterion of public reasoning, the criterion of consensual behaviour also derives from the idea of deliberative democracy because it is in line with the claim of deliberative democracy that political action, and thus also NGO action, must be oriented towards consensus in order to mark a difference from more conflict-oriented modes of political action that focus on bargaining and negotiating (Besson and Martí 2006: xviii). According to discourse ethics, which lies at the basis of deliberative democracy, bargaining is a process which actors enter with the goal of promoting their self-interests whereas in the case of consensual behaviour as represented by deliberation their primary intention is to achieve mutual understanding and, if possible, mutual agreement. An orientation towards consensus does not mean that deliberation necessarily ends in an agreement. However, consensual behaviour is made manifest in the principle willingness to achieve a shared position. Bargaining, in comparison, refers to a situation where the involved actors come with fixed preferences which they aim to defend throughout the discourse. They focus on their own interests and not on the common good. Consensual behaviour by contrast aims at reducing and avoiding conflicts and on discursively aligning private and public interests. In this sense, consensual behaviour is the most meaningful mode of political action for the representation of normative claims (Peters 1997; McCarthy 1994). Thus by choosing consensual over conflict-oriented behaviour, NGOs underline their special status as representatives of the common good.

It should be noted that the term 'consensual behaviour' refers only to the consensual character of the means that NGOs choose to promote their goals and must not be confused with consensus as a goal of NGO action. Under the condition of pluralism, a consensus might not be possible and deliberation might rather result in a "workable agreement" (Young 2001) or "reasonable disagreement" (Gutmann and Thompson 2004). Setting consensus as a goal would imply an overly harmonious account of the result of the interaction between NGOs and companies (on the problem of dealing with conflict in deliberative democracy see Mansbridge 2006). ${ }^{3}$ Hence, the deliberative approach characterizes accountable NGOs as organizations 
which orient themselves towards consensual behaviour (see Young 2001). Young accurately points out that this orientation exemplarily sets them apart from other actors whose behaviour is oriented towards conflict: "An interest group approach to politics encourages people to organize groups to promote particular ends through politics and policy by pressuring or cajoling policy makers to serve those interests. By means of lobbying, buying political advertisements, . . . interest groups further their goals and defeat their opponents" (Young 2001: 674). While NGOs might also use advertisements and lobbyism and, as described, various forms of symbolic conflict behaviour, they do so to pressure corporations into a discourse. The above mentioned example of Timberland being attacked by Greenpeace shows that through the use of non-discursive tactics, Greenpeace was able to convince Timberland to tackle the issue with their assistance (Swartz 2010). Civil society actors pursuing conflict-oriented tactics without any motivation for deliberation signal a lack of consensual behaviour.

Just as with non-discursive behaviour, there are also cases when resorting to discursive but conflict-oriented behaviour is justified. Discursive but conflict-oriented behaviour can be called "dissensual communication" (Palazzo and Scherer 2006: 82). Dissensual communication is especially likely to occur in the case of valuebased instead of interest-based dialogues such as, for example, a dialogue between an NGO which categorically fights child labour and a company which is suspected of using child labour (see Rowley and Moldoveanu 2003 on the difference between interest- and value-based conflicts). A corporation and an NGO might, for instance, agree that child labour is not acceptable. However, they might disagree on the framing of the issue: While the company might explain it by local poverty, corruption or traditions, the NGO might see the company itself as the root cause of the problem. Dissensual communication can be found in particular at the beginning of processes of deliberation, when the actors lack experience in deliberation, have been in confrontation and lack mutual trust. In this case, communication cannot be expected to be consensual right from the start, but as long as the interaction is still discursive, the result could at least be reasonable disagreement. Gutmann and Thompson claim that for disagreement to be reasonable, the parties involved should practice the "economy of moral disagreement" (Gutmann and Thompson 2004). This means that someone's view on one issue "should not affect how she is treated in other respects" (Gutmann and Thompson 2004: 88). Dissensual communication is still characterized by the willingness of the involved parties to continue the discourse, to better understand a problem and the position of the others and to come to a mutual agreement.

If we summarize the findings from assessing the different criteria along the procedural dimension, we can conclude that procedural criteria provide significant normative orientation for judging the moral legitimacy of NGOs. In comparison to the criteria assessed in the substantive and structural dimensions, their particular strength consists in accounting for the fine lines between NGOs and related actors that do not have the same moral legitimacy. However, to be applicable in practice, they need to be further refined. 


\section{CONCLUSIONS}

The legitimacy of NGOs has become a highly relevant question in the CSR debate. In this article, we have argued that the most relevant type of legitimacy of current or potential partner NGOs is their moral legitimacy. By linking it to the normative political theory of deliberative democracy, we have argued that the moral legitimacy of NGOs is best evaluated along procedural criteria. A procedural characterization of NGO legitimacy yields criteria allowing us to capture the essence of NGOs as representatives of the common good as well as the fine lines between them and related actors which might raise similar claims but which fail to prove them in accordance with the concept of moral legitimacy.

This article has provided a general framework for understanding NGO legitimacy. Future research will need to elaborate on the criteria that have been proposed for defining 'legitimate partner NGOs' in more detail for any given kind of situation in which they might be applied.

On a conceptual level, the criteria suggested for judging legitimate partner NGOs need to be further refined. For example, what do legitimate procedures look like in detail? If they are meant to serve as criteria which corporations can check when choosing their partner NGOs, attributes such as 'discursive' and 'consensual' must be specified in more depth. How could the blurred boundaries between NGOs and related actors which can pose a threat to an NGO's moral legitimacy, also be used as a basis for reflecting on a potential division of tasks among different actor types? What role do alliances between NGOs and activists and interest groups play (Snow, Soule, and Kriesi 2004)? Finally, from a dynamic perspective one could reflect on the relevance of the life cycle which NGOs, at least according to some authors (e.g., SustainAbility 2003; Rucht 1999; Avina 1993), follow by developing from loosely organized groups into highly-professional, inevitably business-oriented organizations.

Once the procedural criteria have been refined, it would be interesting to make them fruitful on an empirical level. This could for example happen by integrating them into an existing accountability framework such as the GAP (Government Accountability Project) framework (Blagescu, de las Casa, and Lloyd 2005). The GAP framework unpacks accountability into the four dimensions of transparency, participation, evaluation and complaint and response mechanisms. All these dimensions implicitly contain aspects of moral legitimacy. Making moral legitimacy an explicit and systematic parameter in such an accountability framework would be a way to assess its empirical adequacy. It will also be interesting to assess the criteria against the background of different cultures or different industries which might have another understanding of what constitutes discursive behaviour. Another factor that could contribute to a richer understanding of NGO legitimacy is power. How does the power of the actors involved influence their discursive style? How do corporations and NGOs deal with dissensual situations? Under what conditions does such a dissensus lead to a reasonable form of disagreement with constructive solutions for the problems at stake and under what conditions does dissensus lead to more destructive relations? What is the role of language in the interaction between 
NGOs and corporations? How do language games influence the success or failure of cooperation?

Another venue which might benefit from criteria to assess the moral legitimacy of partner NGOs are multi-stakeholder initiatives such as the UN Global Compact. The Global Compact assigns NGOs an important role and encourages them to not only engage companies but to also provide commentary to companies on their Communications in Progress (United Nations Global Compact 2009). However, the Global Compact puts more emphasis on corporate accountability than on the legitimacy of the NGOs involved since NGOs, unlike corporations, are not required to submit a Communications in Progress. The positive role that NGOs are ascribed in the Global compact would be more credible if it was complemented by some principles by which they could be held accountable. Requiring NGOs to commit themselves to moral legitimacy along the lines of this article would be one way to achieve this.

Last, but not least, this article also yields implications for practitioners in corporations. Managers should by now have realized that partnerships with NGOs cannot be uncritically hailed as a panacea for all CSR issues but are instead exposed to an increasing amount of public scrutiny. They are thus well-advised to actively consider tools and procedures such as accountability standards (Laufer 2003; Rasche and Esser 2006) which help them make their choice of partner NGOs as transparent as possible. A well-informed choice of partner NGOs reduces the risk of rushing into partnerships that pose a threat to a corporation's reputation. The criteria presented in this article give corporations some suggestions on what kind of NGOs they should not cooperate with. A clear stance on how they choose their partner NGOs helps corporations justify why they might not be willing to cooperate with certain groups which raise seemingly legitimate public claims but which are interested in discrediting the corporation rather than in constructive engagement.

Once they have adapted the criteria for judging the moral legitimacy of partner NGOs according to their specific needs and circumstances, corporations could use these criteria in the process of defining the terms of collaboration when a specific partnership takes form. They could also incorporate them in their CSR policy and mission statement and rely on them when developing a written NGO partnership policy. Finally, the criteria for moral legitimacy could also help when evaluating a partnership. Depending on how a partner NGO maintains its moral legitimacy, a corporation can take reasonable and justified decisions about the continuation or cancellation of the partnership.

\section{NOTES}

Previous drafts of this paper were presented at the 2008 EGOS conference, Amsterdam (NL), July 10-12, 2008; at the Annual Meeting of the Academy of Management in Anaheim (US), August 8-13, 2008; and at the Society for Business Ethics Annual Meeting. Montreal (CAN). August 6-10, 2010. We thank Business Ethics Quarterly editor Gary Weaver as well as three anonymous reviewers for their helpful comments. We particularly acknowledge the kind assistance of Gary Weaver in the editing of the final manuscript.

1. As a recent study on the perception of NGOs by other stakeholders in Spain has shown, the legitimacy of NGOs is not only an issue of concern for corporations but also for other stakeholders (Arenas, Lozano, and Albareda 2009). 
2. We derive this admittedly rough definition of un-civil behaviour from considering un-civil behaviour as the opposite of 'civil disobedience' which is by definition non-violent (Thomassen 2007).

3. There is a dispute among deliberative democrats. Gutmann and Thompson distinguish between "consensus democrats" who aim at achieving consensus through realizing a common good and pluralists who aim at living respectfully with moral disagreements - for the latter, some moral disagreements "are inherent in the human condition" (Gutmann and Thompson 2004: 27) while consensus democrats state that a "thick common good" must be the goal of deliberation, otherwise there will never be "a community in which citizens find a common ground at the deepest level of their social identities" (Gutmann and Thompson 2004: 27). Thus, if the term consensus only refers to the consensual character of the methods that NGOs deploy, this does not preclude disagreement as a result. However, the disagreement must be reasonable; that is, it must relate only to "conflicts not between views that are clearly right and clearly wrong, but between views none of which can be reasonably rejected" (Gutmann and Thompson 2004: 28).

\section{REFERENCES}

Apollonio, D. E., and L. A. Bero. 2007. "The Creation of Industry Front Groups: The Tobacco Industry and 'Get Government Off Our Back," American Journal of Public Health 97(3): 419-27.

Arenas, D., J. M. Lozano, and L. Albareda. 2009. "The Role of NGOs in CSR: Mutual Perceptions among Stakeholders," Journal of Business Ethics 88(1): 175-97.

Argenti, P. A. 2004. "Collaborating with Activists: How Starbucks works with NGOs," California Management Review 47(1): 91-116.

Arnold, D. G., and N. E. Bowie. 2003. "Sweatshops and Respect for Persons," Business Ethics Quarterly 13(2): 221-42.

Ashforth, B. E., and B. W. Gibbs. 1990. "The Double-Edge of Organizational Legitimation," Organization Science 1(2): 177-94.

Avina, J. 1993. "The Evolutionary Life Cycles of Non-Governmental Development Organizations," Public Administration \& Development 13(5): 453-74.

Banerjee, S. B. 2000. "Whose Land Is It Anyway? National Interest, Indigenous Stakeholders, and Colonial Discourses," Organization \& Environment 13(1): 3-38.

Beck-Gernsheim, E., and U. Beck. 2002. Individualization: Institutionalized Individualism and its Social and Political Consequences. London: Sage.

Bendell, J. 2005. "In Whose Name? The Accountability of Corporate Social Responsibility," Development in Practice 15(3): 362-74.

Benhabib, S. 1992. Situating the Self: Gender, Community and Postmodernism in Contemporary Ethics. Cambridge: Polity Press.

1994. "Deliberative Rationality and Models of Democratic Legitimacy," Constellations: An International Journal of Critical \& Democratic Theory 1(1): 26-52.

1996. Democracy and Difference: Contesting the Boundaries of the Political. Princeton, N.J.: Princeton University Press.

2002. The Claims of Culture: Equality and Diversity in the Global Era. Princeton, N.J.: Princeton University Press.

Besson, S., and J. L. Martí. 2006. "Introduction," in Deliberative Democracy and Its Discontents, xiii-xxxi. Aldershot: Ashgate. 
Billenness, S. 2003. "Business-NGO Partnership in Globalization: Sustainability through StrategicPartnerships,"http://www.gemi.org/docs/conf2003/SimonBillenness_files/ frame.htm; first accessed August 15, 2006.

Blagescu, M., L. de las Casa, and R. Lloyd. 2005. Pathways to Accountability: The GAP Framework. London: One World Trust.

Bohman, J. 1998. "Survey Article: The Coming of Age of Deliberative Democracy," Journal of Political Philosophy 6(4): 400-25.

Boyle, C. 2009. “Extremists' Attacks on Novartis Chief Intensify,” Times (London) (August 7): 43.

Braithwaite, J., and P. Drahos. 2000. Global Business Regulation. Cambridge: Cambridge University Press.

Brown, L. D. 2008. Creating Credibility: Legitimacy and Accountability for Transnational Civil Society. Sterling, Va.: Kumarian Press.

Buchanan, J. M. 1987. "The Constitution of Economic Policy," American Economic Review 77(3): 243-50.

Chambers, S. 2003. "Deliberative Democratic Theory," Annual Review of Political Science 6(1): 307-26.

Chandhoke, N. 2005. "How Global Is Global Civil Society?," Journal of World-Systems Research 11(2): 355-71.

Cohen, J. 1989. "Deliberation and Democratic Legitimacy," in The Good Polity, ed. A. Hamlin and B. Petit, 17-34. New York: Basil Blackwell.

Cohen, J. L. 1999. "Trust, Voluntary Association and Workable Democracy: The Contemporary American Discourse of Civil Society," in Democracy and Trust, ed. M. E. Warren, 208-48. Cambridge: Cambridge University Press.

Collingwood, V., and L. Logister. 2005. "State of the Art: Addressing the INGO 'Legitimacy Deficit," Political Studies Review 3(2): 175-92.

Cooke, M. 2000. "Five Arguments for Deliberative Democracy," Political Studies 48(5): 947-69.

Crane, A., and D. Matten. 2007. Business Ethics: Managing Corporate Citizenship and Sustainability in the Age of Globalization. Oxford: Oxford University Press.

Dahan, N. M., J. P. Doh, J. Oetzel, and M. Yaziji. 2010. "Corporate-NGO Collaboration: Co-Creating New Business Models for Developing Markets," Long Range Planning 43(2-3): 326-42.

Dahl, R. A. 1956. A Preface to Democratic Theory. New Haven, Conn.: Yale University Press.

Dalberg Global Development Advisors. 2007. "The Business Guide to Partnering with NGOs and the UN. Executive Summary," http://www.dalberg.com/guide/guide _preview.pdf; first accessed July 5, 2007.

De Bakker, F. G. A., and F. Den Hond. 2008. "Introducing the Politics of Stakeholder Influence: A Review Essay,” Business \& Society 47(1): 8-20.

Den Hond, F., and F. G. A. De Bakker. 2007. "Ideologically Motivated Activism: How Activist Groups Influence Corporate Social Change Behavior," Academy of Management Review 32(3): 901-24. 
Doh, J. P., and T. R. Guay. 2006. "Corporate Social Responsibility, Public Policy, and NGO Activism in Europe and the United States: An Institutional-Stakeholder Perspective," Journal of Management Studies 43(1): 47-73.

Doh, J. P., and H. Teegen. 2002. "Nongovernmental Organizations as Institutional Actors in International Business: Theory and Implications," International Business Review 11(6): 665-84.

Dowling, J., and J. Pfeffer. 1975. "Organizational Legitimacy: Social Values and Organizational Behavior,” Pacific Sociological Review 18(1): 122-36.

Downs, A. 1957. An Economic Theory of Democracy. New York: Harper and Brothers.

Dryzek, J. S. 1999. “Transnational Democracy,” Journal of Political Philosophy 7(1): 30-51. 2000. Deliberative Democracy and Beyond. Liberals, Critics, Contestations. New York: Oxford University Press.

2006. Deliberative Global Politics: Discourse and Democracy in a Divided World. Cambridge: Polity Press.

Ebrahim, A. 2003. “Accountability in Practice: Mechanisms for NGOs," World Development 31(5): 813-29.

Edwards, R. 2009. "Huntingdon Activists Linked to Attack on Swiss Villa," Daily Telegraph (London) (August 6): 5.

Elsbach, K. D., and R. I. Sutton. 1992. "Acquiring Organizational Legitimacy through Illegitimate Actions: A Marriage of Institutional And Impression Management Theories," Academy of Management Joumal 35(4): 699-738.

Fashion United. 2006. "Peta attacks Julien MacDonald," http://www.fashionunited.co.uk/ news/peta.htm; first accessed December 2009.

Forster Company, The, and TwentyFifty Ltd. 2005. "Collaboration in Context: On the Use of International Standards in NGO-business Partnerships," http://www .theforstercompany.co.uk/docs/TFCPartnershipreportJune.pdf; accessed September 10, 2006.

Fort, T. L., and C. A. Schipani. 2004. The Role of Business in Fostering Peaceful Societies. Cambridge: Cambridge University Press.

Fowler, A. 2000. Civil Society, NGDOs and Social Development: Changing the Rules of the Game. Geneva: UNRISD.

Friedman, J., and S. Randeria, eds. 2004. Worlds on the Move: Globalisation, Migration and Cultural Security. London: Tauris.

Fries, R. 2003. "The Legal Environment of Civil Society," in The Global Civil Society Yearbook 2003, ed. M. Kaldor, H. Anheier, and M. Glasius, 221-38. Oxford: Oxford University Press.

Fung, A. 2003. "Deliberative Democracy and International Labor Standards," Governance 16(1): 51-71.

2005. "Deliberation before the Revolution: Toward an Ethics of Deliberative Democracy in an Unjust World," Political Theory 33(3): 397-419.

Gartzke, U. 2004. "Power and Counter-Power? Multinational Corporations and NGOs in the Age of Globalization," www.ngowatch.org/articles/2004.pdf; first accessed August 17, 2006. 
Gaus, G. F. 2003. Contemporary Theories of Liberalism: Public Reason as a PostEnlightenment Project. London: Sage.

Gilbert, D. U., and A. Rasche. 2007. "Discourse Ethics and Social Accountability: The Ethics of SA 8000," Business Ethics Quarterly 17(2): 187-216.

Goodstein, J. D., and A. C. Wicks. 2007. "Corporate and Stakeholder Responsibility: Making Business Ethics a Two-Way Conversation,” Business Ethics Quarterly 17(3): 375-98.

Gray, R., J. Bebbington, and D. Collison. 2006. "NGOs, Civil Society and Accountability: Making the People Accountable to Capital," Accounting, Auditing \& Accountability Journal 19(3): 319-48.

Guay, T., J. P. Doh, and G. Sinclair. 2004. "Non-Governmental Organizations, Shareholder Activism, and Socially Responsible Investments: Ethical, Strategic, and Governance Implications," Journal of Business Ethics 52(1): 125-39.

Gutmann, A., and D. Thompson. 2004. Why Deliberative Democracy? Princeton, N.J.: Princeton University Press.

Habermas, J. 1990. Moral Consciousness and Communicative Action. Cambridge, Mass.: MIT Press.

1996a. Between Facts and Norms. Cambridge: Polity Press.

1996b. "Three Normative Models of Democracy," in Democracy and Difference: Contesting the Boundaries of the Political, ed. S. Benhabib, 21-30. Princeton, N.J.: Princeton University Press.

2001. The Postnational Constellation: Political Essays. Cambridge: Polity Press.

Habermas, J., and C. Cronin. 2006. The Divided West. Cambridge: Polity Press.

Haines, H. H. 1984. "Black Radicalization and the Funding of Civil Rights: 1957-1970," Social Problems 32(1): 31-43.

Hall, R. B., and T. J. Biersteker. 2002. "The Emergence of Private Authority in the International System," in The Emergence of Private Authority in Global Governance, ed. R. B. Hall and T. J. Biersteker, 3-22. Cambridge: Cambridge University Press.

Hamann, R., and N. Acutt. 2003. "How Should Civil Society (and the Government) Respond to 'Corporate Social Responsibility'? A Critique of Business Motivations and the Potential for Partnerships," Development Southern Africa 20(2): 255-70.

Hendry, J. R. 2006. "Taking Aim at Business: What Factors Lead Environmental NonGovernmental Organizations to Target Particular Firms?," Business and Society 45(1): 47-86.

Humphrey, M., and M. Stears. 2006. "Animal Rights Protest and the Challenge to Deliberative Democracy," Economy and Society 35(3): 400-22.

Ignatieff, M., and A. Gutmann. 2001. Human Rights as politics and Idolatry. Princeton, N.J.: Princeton University Press.

International Council on Human Rights Policy. 2003. Deserving Trust: Issues of Accountability for Human Rights NGOs (Draft Report for Consultation). Geneva: International Council on Human Rights Policy. 
Jack, A. 2009. "Novartis Blames Animal Militants for Raid," Financial Times (London) (August 4). http://www.ft.com/cms/s/0/b8a08d8a-8137-11de-92e7-00144feabdc0 .html\#axzz1SRUQpAQB.

Jones, T. M., and A. C. Wicks. 1999. "Convergent Stakeholder Theory," Academy of Management Review 24(2): 206-21.

Jonker, J., and A. Nijhof. 2006. "Looking through the Eyes of Others: Assessing Mutual Expectations and Experiences in Order to Shape Dialogue and Collaboration between Business and NGOs with Respect to CSR," Corporate Governance: An International Review 14(5): 456-66.

Kapstein, E. B. 2001. “The Corporate Ethics Crusade,” Foreign Affairs 80(5): 105-19.

Kaul, I., P. Conceição, K. Le Goulven, and R. U. Mendoza. 2003. Providing Global Public Goods. Oxford: Oxford University Press.

King, L. E. 2003. "Deliberation, Legitimacy, and Multilateral Democracy," Governance 16(1): 23-50.

Kobrin, S. J. 2001. "Sovereignty@bay: Globalization, Multinational Enterprise, and the International Political System," in The Oxford Handbook of International Business, ed. A. M. Rugman and T. L. Brewer, 181-205. New York: Oxford University Press.

2009. "Private Political Authority and Public Responsibility: Transnational Politics, Transnational Firms, and Human Rights," Business Ethics Quarterly 19(3): 349-74.

Kostova, T., and K. Roth. 2002. "Adoption of an Organizational Practice by Subsidiaries of Multinational Corporations: Institutional and Relational Effects," Academy of Management Journal 45(1): 215-33.

Lash, S. 1999. Another Modernity: A Different Rationality. Oxford: Wiley-Blackwell.

Laufer, W. S. 2003. "Social Accountability and Corporate Greenwashing," Journal of Business Ethics 43(3): 253-61.

Leggewie, C. 2003. "Transnational Movements and the Question of Democracy," http:// www.eurozine.com/articles/2003-02-03-leggewie-en.html; first accessed May 20, 2007.

Livesey, S. M. 2001. "Eco-Identity as Discursive Struggle: Royal Dutch/Shell, Brent Spar, and Nigeria," Journal of Business Communication 38(1): 58-91.

Lozano, F. 2001. "Proposal for a Model for the Elaboration of Ethical Codes Based on Discourse Ethics," Business Ethics, A European Review 10(2): 157-62.

Manin, B. 1987. “On Legitimacy and Political Deliberation,” Political Theory 15(3): 338-68.

Mansbridge, J. 2006. "Conflict and Self-Interest in Deliberation," in Deliberative Democracy and Its Discontents, ed. S. Besson and J. L. Martí, 107-32. Aldershot: Ashgate.

Margolis, J. D., and J. P. Walsh. 2003. "Misery Loves Companies: Rethinking Social Initiatives by Business," Administrative Science Quarterly 48: 268-305.

Martens, K. 2002. "Mission Impossible? Defining Nongovernmental Organizations," Voluntas: Journal of Voluntary and Nonprofit Organizations 13(3): 271-85.

Matten, D., and A. Crane. 2005. "Corporate Citizenship: Toward an Extended Theoretical Conceptualization," Academy of Management Review 30(1): 166-79. 
McCarthy, T. 1994. "Kantian Constructivism and Reconstructivism: Rawls and Habermas in Dialogue," Ethics 105(1): 44-63.

Mitchell, R. K., B. R. Agle, and D. Wood. 1997. "Toward a Theory of Stakeholder Identification and Salience: Defining the Principle of Who and What Really Counts," Academy of Management Review 22(4): 853-86.

Moon, J., A. Crane, and D. Matten. 2005. "Can Corporations Be Citizens? Corporate Citizenship as a Metaphor for Business Participation in Society," Business Ethics Quarterly 15(3): 429-53.

Moon, J. D. 2003. "Rawls and Habermas on Public Reason: Human Rights and Global Justice," Annual Review of Political Science 6: 257-74.

Nanz, P., and J. Steffek. 2004. "Global Governance, Participation and the Public Sphere," Government and Opposition 39(2): 314-35.

Nijhof, A., T. de Bruijn, and H. Honders. 2008. "Partnerships for Corporate Social Responsibility: A Review of Concepts and Strategic Options," Management Decision 46(1): 152-67.

Palazzo, G., and A. G. Scherer. 2006. "Corporate Legitimacy as Deliberation: A Communicative Framework," Journal of Business Ethics 66(1): 71-88.

2008. "Corporate Social Responsibility, Democracy, and the Politicization of the Corporation," Academy of Management Review 33(3): 773-75.

PETA. 2007. "Mayhem at the Christian Lacroix Fashion Show," http://blog.peta.org/ archives/2007/02/mayhem_at_the_c.php; first accessed November 2009.

Peters, B. 1997. "On Public Deliberation and Public Culture: Reflections on the Public Sphere," IIS-Arbeitspapier 97(7), http://www.iniis.uni-bremen.de/; accessed November 20, 2006.

Phillips, R. 2003. “Stakeholder Legitimacy,” Business Ethics Quarterly 13(1): 25-41.

Phillips, R. A., and R. E. Freeman. 2008. "Corporate Citizenship and Community Stakeholders," in Handbook of Research on Global Corporate Citizenship, ed. A. G. Scherer and G. Palazzo, 99-115. Cheltenham: Edward Elgar.

Rasche, A., and D. E. Esser. 2006. "From Stakeholder Management to Stakeholder Accountability," Journal of Business Ethics 65(3): 251-67.

Rawls, J. 1993. Political Liberalism. New York: Columbia University Press.

Reynolds, M., and K. Yuthas. 2008. "Moral Discourse and Corporate Social Responsibility Reporting," Journal of Business Ethics 78(1-2): 47-64.

Risse, T. 2004. "Global Governance and Communicative Action," Government and Opposition 39(2): 288-313.

Roloff, J. 2008. "Learning from Multi-Stakeholder Networks: Issue-Focussed Stakeholder Management," Journal of Business Ethics 82(1): 233-50.

Rondinelli, D. A., and T. London. 2003. "How Corporations and Environmental Groups Cooperate: Assessing Cross-Sector Alliances and Collaborations," Academy of Management Executive 17(1): 61-76.

Rorty, R. 1991. "The Priority of Democracy to Philosophy," in Objectivity, Relativism, and Truth: Philosophical Papers, vol. 1, ed. R. Rorty, 175-96. Cambridge: Cambridge University Press. 
Rowley, T. I., and M. Moldoveanu. 2003. "When Will Stakeholder Groups Act? An Interest- and Identity-Based Model of Stakeholder Group Mobilization," Academy of Management Review 28(2): 204-19.

Rucht, D. 1999. “Linking Organizations and Mobilization: Michels's Iron Law of Oligarchy Reconsidered," Mobilization 4: 151-69.

Santoro, M. A. 2009. China 2020. Ithaca, N.Y.: Cornell University Press.

Scherer, A. G., and G. Palazzo. 2007. "Toward a Political Conception of Corporate Responsibility: Business and Society Seen from a Habermasian Perspective," Academy of Management Review 32(4): 1096-1120.

. 2011. "The New Political Role of Business in a Globalized World: A Review of a New Perspective on CSR and its Implications for the Firm, Governance, and Democracy," Journal of Management Studies 48(4): 899-931.

Scherer, A. G., G. Palazzo, and D. Baumann. 2006. "Global Rules and Private Actors: Toward a New Role of the Transnational Corporation in Global Governance," Business Ethics Quarterly 16(4): 505-32.

Schiller, B. 2005. "Ethical Corporation Report: Business-NGO Partnerships," http:// earthmind.net/ngo/docs/partnerships-overview.pdf.

Schumpeter, J. A. 1947. Capitalism, Socialism, and Democracy. New York: Harper.

Slim, H. 2002. By What Authority? The Legitimacy and Accountability of NGOs. The International Council on Human Rights Policy International Meeting on "Global Trends and Human Rights: Before and after September 11," Geneva, January 10 12, 2002.

Smith, J. 1998. "Global Civil Society?," The American Behavioral Scientist 42(1): 93-107.

Snow, D. A., S. A. Soule, and H. Kriesi. 2004. "Mapping the Terrain," in The Blackwell Companion to Social Movements, ed. D. A. Snow, S. A. Soule, and H. Kriesi, 3-16. Malden, Mass.: Blackwell.

Spar, D. L., and L. T. La Mure. 2003. "The Power of Activism: Assessing the Impact of NGOs on Global Business," California Management Review 45(3): 78-101.

Suchman, M. C. 1995. "Managing Legitimacy: Strategic and Institutional Approaches," Academy of Management Review 20(3): 571-610.

SustainAbility. 2003. The 21st Century NGO: In the Market for Change. London: SustainAbility.

Swartz, J. 2010. “Timberland's CEO on Standing Up to 65,000 Angry Activists," Harvard Business Review (September): 39-43.

Taylor, C. 2007. A Secular Age. Cambridge, Mass.: Belknap.

Teegen, H., J. P. Doh, and S. Vachani. 2004. "The Importance of Nongovernmental Organizations (NGOs) in Global Governance and Value Creation: An International Business Research Agenda," Journal of International Business Studies 35(6): 463-83.

Thomassen, L. 2007. "Within the Limits of Deliberative Reason Alone: Habermas, Civil Disobedience and Constitutional Democracy," European Journal of Political Theory 6(2): 200-18. 
Tucker, L., and T. C. Melewar. 2005. "Corporate Reputation and Crisis Management: The Threat and Manageability of Anti-Corporatism," Corporate Reputation Review 7(4): 377-87.

Ulrich, P. 2008. Integrative Economic Ethics: Foundations of a Civilized Market Economy. Cambridge: Cambridge University Press.

United Nations Department of Public Information. 2006. "Criteria: What Is an NGO?, http://www.un.org/dpi/ngosection/criteria.html; first accessed June 10, 2006.

United Nations Economic and Social Council. 1996. Consultative Relationship between the United Nations and Non-Governmental Organizations. Resolution 1996/31.

United Nations Global Compact. 2009. "Civil Society in the Global Compact," http://www .unglobalcompact.org/HowToParticipate/civil_society/index.html; first accessed December 1, 2009.

Utting, P. 2005. "Corporate Responsibility and the Movement of Business," Development in Practice 15(3 \& 4): 375-88.

Vachani, S., J. P. Doh, and H. Teegen. 2009. "NGOs' Influence on MNEs' Social Development Strategies in Varying Institutional Contexts: A Transaction Cost Perspective," International Business Review 18(5): 446-56.

Valente, M., and A. Crane. 2010. "Public Responsibility and Private Enterprise in Developing Countries," California Management Review 52(3): 52-78.

van Huijstee, M., and P. Glasbergen. 2010. "Business-NGO Interactions in a MultiStakeholder Context," Business and Society Review 115(3): 249-84.

Vogel, D. 2007. "Private Global Business Regulation," Annual Review of Political Science 11: 261-82.

Warren, M. E. 1996. "Deliberative Democracy and Authority," American Political Science Review 90(1): 46-60.

Weintraub, J. 1997. Public and Private in Thought and Practice: Perspectives on a Grand Dichotomy. Chicago: University of Chicago Press.

Wettstein, F. 2010. "The Duty to Protect: Corporate Complicity, Political Responsibility, and Human Rights Advocacy," Journal of Business Ethics 96(1): 33-47.

Yaziji, M., and J. P. Doh. 2009. NGOs and Corporations: Conflict and Collaboration. Cambridge: Cambridge University Press.

Young, I. M. 2001. "Activist Challenges to Deliberative Democracy," Political Theory 29(5): 670-90.

Zürn, M. 1999. "The State in the Post-National Constellation: Societal Denationalization and Multi-Level Governance," Arena Working Papers, 99/35.

2004. "Global Governance and Legitimacy Problems," Government and Opposition 39(2): 260-87. 